\title{
Author: A Saurombe
}

THE ROLE OF SADC INSTITUTIONS IN IMPLEMENTING SADC TREATY PROVISIONS

DEALING WITH REGIONAL INTEGRATION

\section{ISSN 1727-3781}

2012 VOLUME 15 No 2

http://dx.doi.org/10.4314/pelj.v15i2.16 


\section{THE ROLE OF SADC INSTITUTIONS IN IMPLEMENTING SADC TREATY PROVISIONS DEALING WITH REGIONAL INTEGRATION}

A Saurombe**

The Southern African Development Community (SADC) Treaty constitutes not only a statement of intent and resolve to overcome the burden of history but also an acknowledgement of the immense benefits of regional economic integration. ${ }^{1}$ The SADC Treaty, its various institutions and legal instruments constitute an important step in the direction of integration. ${ }^{2}$ The challenge now is how SADC Member States are willing to subject themselves to supranational governance as provided for by the Treaty and implemented by the key institutions that also derive their mandate from the Treaty. Among the many interventions that can be employed, the SADC needs the political consensus necessary among its Member States and the technical capacity required among those charged with the responsibility for such a task for both an unequivocal commitment to deep integration and the full acceptance of the inevitable, but short-lived, political costs of such an undertaking. ${ }^{3}$

Sovereign states of the SADC will undoubtedly feel the effects integration will have on their sovereignty. However, it has to be pointed out here that the SADC came into being within the context of a freely concluded agreement; hence, the fear of supranational structures of the organisation jeopardising national sovereignty is not convincing. ${ }^{4}$ Supranational structures do not limit the sovereignty of Member States, because they are established as a result of negotiated power vested in a political entity that may not necessarily have the power to enforce its authority. The concept

* Amos Saurombe. LLB (Fort Hare), LLM (UWC, Amsterdam Law School). LLD (North West University (Potchefstroom)) Senior Lecturer, Mercantile Law Department, University of South Africa, sauroa@unisa.ac.za.

$1 \quad$ Maruping "Challenges for Integration". The burden of history discussed here refers to past years of colonialism, underdevelopment and economic hardships that seem to have worsened even after the independence of the whole region.

2 Evans, Holmes and Mandaza SADC 12.

3 Saurombe Regionalisation 313-315.

4 See generally Ferrari and Pollicino 2011 Comparative Law Review. 
of supranational union is sometimes used to describe the European Union as a new type of political entity. ${ }^{5}$

The undertaking to uphold supranational authority has to be anchored in the legal framework of the SADC Treaty and its Protocols. SADC institutions are thus empowered by these legal instruments to play a meaningful role in regional integration. Erasmus ${ }^{6}$ poses a number of relevant questions which governments involved in regional integration will have to address. These are: 'What are the implications of the treaty obligations for the parties' citizens?; How will their national policies be affected?; and What happens in the case of non-compliance?' This paper does not answer these questions exhaustively but provides an analysis of the legal provisions that form the basis of the functioning of key SADC institutions. In addition, Erasmus observes that:

The more comprehensive the trade arrangements and the more advanced the integration process, the stronger the need for appropriate institutions with supranational powers. ${ }^{7}$

Thus, the drive towards deeper integration in the SADC should equally be supported by stronger supranational mechanisms and the highest political level in a Member State. Regional economic integration in the SADC will be discussed with a thorough examination of the important institutional and legal structures of the organisation. This discussion will focus on the various institutions whose legal mandate is related to the economic integration process. The institutions are authorised by the Treaty and the Protocol on Trade, among other things to harmonise the political and social economic policies of Member States, and to encourage popular participation in the activities of SADC and the implementation of SADC initiatives. ${ }^{8}$

5 Kiljunen European Constitution in the Making 21-26.

6 Erasmus 2011 SADC Law Journal 17.

7 Erasmus 2011 SADC Law Journal 17.

8 Saurombe Regionalisation 313-315. 


\section{Background}

The countries in Southern Africa have been key drivers of the new global proliferation of regional trade agreements (RTAs). ${ }^{9}$ Consequently, Southern Africa has taken its place on the global stage, mainly because of the existence of the Southern African Development Community (SADC). ${ }^{10}$ Before the signing of the SADC Treaty, the organisation was run under a loose and non-binding structure of the Southern African Development Coordination Conference (SADCC). ${ }^{11}$ The origins of the SADCC lie in the Frontline States, ${ }^{12}$ a group of Southern African countries that fought for independence from colonial rule. Their aim was to help liberate the whole region from colonial rule. In the 1960s and 70s, these newly independent states supported national liberation movements in the region by coordinating their political, diplomatic and military struggle to bring an end to colonial and white minority rule. The idea was to secure international cooperation for economic liberation and collective self-reliance. ${ }^{13}$ At that time, according to the late President of Botswana, Sir Seretse Khama, "economic dependence had in many ways made political independence somewhat meaningless". ${ }^{14}$ An additional effort under former President Kaunda of Zambia was to establish a transcontinental belt of independent and economically powerful nations from Dar es Salaam and Maputo on the Indian Ocean to Luanda on the Atlantic. ${ }^{15}$

9 Hereafter "RTAs". The members of the SADC are Angola, Botswana, Democratic Republic of Congo, Lesotho, Malawi, Mauritius, Mozambique, Namibia, Seychelles, South Africa, Swaziland, Tanzania, Zambia and Zimbabwe. The membership of Madagascar was suspended after a coup d'état by opposition leader Andre Rajoelena.

10 Hereafter the "SADC". For a historical background limited to up to 1985 see Abegunrin 1981-2 Current Bibliography on African Affairs 1-5.

11 Oosthuizen Southern African Development Community 17. See also Abegunrin "Southern African Development Coordination Conference" 36. The Southern African Development Co-ordination Conference was established in 1980 by the governments of Angola, Botswana, Lesotho, Malawi, Mozambique, Swaziland, Tanzania, Zambia and Zimbabwe, which was the forerunner of the Southern African Development Community (SADC), which was formed in Lusaka, Zambia, on 1 April 1980, following the adoption of the Lusaka Declaration (1980) by the nine founding member states. See also the Harare Memorandum of Understanding (1981). There was no treaty signed for SADCC.

12 Clough and Ravenhill "Regionalism in Southern Africa". See also Thompson Challenge to Imperialism. See also Nsekela Southern Africa 21

13 Tsikata "Southern Africa: Trade, Liberalisation and Implications" 14. See also Gibb 1998 JMAS 287-306.

14 Khama 1979 Africa Research Bulletin 51-55. See also Gibb 1998 JMAS 287-306.

15 Kaunda "Address" 3-4. 
This de facto regional organisation needed a treaty and a number of other legally binding instruments. ${ }^{16}$ Thus, the SADC was formed as an international regional organisation established in terms of a treaty and declaration referred to as the 'Treaty of Southern African Development Community', signed by the heads of state and government of the signatory Member States. ${ }^{17}$

The SADC Treaty provides the legal framework of the organisation by setting out the status, ${ }^{18}$ principles and objectives, ${ }^{19}$ and obligations of Member States; ${ }^{20}$ the membership, ${ }^{21}$ the institutions, ${ }^{22}$ procedural matters relating to areas of cooperation among Member States, ${ }^{23}$ cooperation with other international organisations, ${ }^{24}$ financial issues, ${ }^{25}$ dispute settlement, ${ }^{26}$ and lastly sanctions, withdrawal and dissolution. ${ }^{27}$ The SADC Treaty makes provision for the formulation of subsidiary legal instruments such as protocols giving specific mandates to various SADC institutions. A total of twenty three protocols have so far been formulated. ${ }^{28}$

\section{SADC institutions supporting regional integration}

In deciding on the SADC's institutional framework, the founders were particularly sensitive to the lessons and experiences of past attempts at regional cooperation in Africa, some of which had ended in failure and bitter disappointment; for example, the collapse of the East Africa Community in $1977 .{ }^{29}$ Such failure was largely because sensitive issues of how best to equitably share the cost and benefits of regional cooperation had not been sufficiently addressed and agreed upon at both

16 Olivier "Southern African Development Community" 15.

17 The SADC Treaty was signed at Windhoek, Namibia on 17 August 1992, entering into force on 30 September 1993. The Treaty was amended at Blantyre, Malawi in August 2001. A consolidated version of the Treaty and all its amendments can be accessed on the SADC official website (SADC Date Unknown www.sadc.int).

18 Article 14 SADC Treaty (1992).

19 Chapter 3 , Aa 4 and 5 SADC Treaty (1992).

20 Article 6 SADC Treaty (1992).

21 Chapter 4 Aa 37 and 8 SADC Treaty (1992).

22 Chapter 5 Aa 9 and 16A SADC Treaty (1992).

23 Article 21 SADC Treaty (1992).

24 Article 24 SADC Treaty (1992).

25 Chapter 9 Aa 25-27 and Chapter 10 Aa 28-30 SADC Treaty (1992).

26 Article 32 SADC Treaty (1992).

27 Chapter 13 Aa 33-35 SADC Treaty (1992).

28 See list of Protocols available on SADC Date Unknown www.sadc.int

29 Mutua 2007 allafrica.com. 
national and regional levels. To avoid similar pitfalls from the beginning, the SADC placed particular emphasis on a decentralised institutional arrangement. This was a deliberate avoidance of supranational institutions. This ensured that Member States are the principal actors in the formation and implementation of policy decisions. The SADC Treaty basically re-enacted the institutional structure of the SADCC. ${ }^{30}$ Thus not much was learnt from the 1980 failures. Deeper integration and trade liberalisation was not going to be realised under a decentralised institutional arrangement. Thus deeper integration and trade liberalisation is not possible under a decentralised institutional arrangement. ${ }^{31}$ Deeper integration requires governance that transcends individual Member States within the region to a level where decision making is delegated to regional institutions that are to some extent independent of Member States' influence. If this is not done, regional institutions might lack democratic legitimacy and may result in the loss of popular support for the whole project. This is important because the nature and extent of the powers vested in regional institutions determines the institutions' ability to promote the region's integration agenda. ${ }^{32}$ Therefore the importance of the existence of supranational institutions in promoting regional integration cannot be overemphasised. ${ }^{33}$ According to Mutharika ${ }^{34}$

Economic integration requires the delegation of power to a supranational body entrusted with the task of safeguarding the interest of both the supranational entity as well as that of the individual Member States.

The principal organs driving regional economic integration in the SADC are the Summit, which is made up of Heads of State and Government; the Troika; the Council of Ministers; the Integrated Committee of Ministers; the Tribunal; SADC National Committees; Standing Committee of Officials; and the Secretariat. The SADC Tribunal was the only new institution provided for under the Windhoek Treaty. For the purposes of this paper only the important institutions relevant to regional integration will be discussed. Each institution will be discussed according to the

30 Jakobeit, Hartzenberg and Charalambides 2005 www.acp-eu-trade.org 12.

31 See generally Mattli 1999. The Logic of Regional Integration 3.

32 Afadameh-Adeyemi and Kalula 2010 Monitoring Regional Integration in Southern Africa: Yearbook 30.

33 Afadameh-Adeyemi and Kalula 2010 Monitoring Regional Integration in Southern Africa: Yearbook 30.

34 Mutharika Towards Multinational Economic Cooperation 31 
provisions of the Treaty and the mandate of the Protocol on Trade. The role of each of these institutions in SADC regional integration is also analysed.

\subsection{The Summit ${ }^{35}$ and its role in regional integration}

The Summit is made up of Heads of State and/or Government from all SADC Member States. The decisions of the Summit are taken by consensus. ${ }^{36}$ It is the ultimate policy-making institution of SADC and is responsible for the overall policy direction and control of functions of the Community. ${ }^{37}$ The Summit is also a legislative organ. ${ }^{38}$ The Summit is described as an organ capable of making decisions that are 'binding'. ${ }^{39}$ The Summit usually meets once or twice a year around August or September in a Member State. ${ }^{40}$ It appoints the Executive Secretary and Deputy Secretary of the Secretariat ${ }^{41}$ and admits new members into SADC. ${ }^{42}$ The official Heads of States and Government Summit for 2008 was held in South Africa where the South African Chairmanship of the Summit presided over the launch of the SADC Free Trade Area (FTA) at the $28^{\text {th }}$ SADC Summit on 18 July $2008 .{ }^{43}$ Speaking at the Summit, the then South African President Thabo Mbeki said SADC Member States needed to assess how best they could advance the integration effort and the region's trade performance, noting that the most serious constraints to growing the region were underdeveloped structures and supply capacity. ${ }^{44}$ The Windhoek Summit of 2010 resolved that SADC should not proceed to form a customs union. ${ }^{45}$ This shows that the Summit plays a critical role in SADC regional integration. Moreover, Article 22(1) of the SADC Treaty places a duty on the Member States,

35 Article 10 SADC Treaty (1992).

36 Article 10 SADC Treaty (1992). The use of consensus by the Summit has compromised its functions, for example the issues surrounding Zimbabwe's refusal to accept the decision of the Tribunal ruling in the Campbell case. This means that for the decision to be endorsed by the Summit, Zimbabwe will have to support it. This was highly unlikely and it became clear that the Summit sided with Zimbabwe and suspended the Tribunal.

37 Ng'ong'ola 1999 Journal of World Trade 485-506.

38 Article 10(3) SADC Treaty (1992) empowers the Summit to adopt legal texts and instruments for the implementation of the Treaty. Some of the work can be delegated to the Council of Ministers.

39 Article 10(8) SADC Treaty (1992).

40 Article 10(5) SADC Treaty (1992).

41 Article 10(7) SADC Treaty (1992).

42 Article 8(2) SADC Treaty (1992).

43 SADC. 2008. Summit Communiqué

44 SADC. 2008. Summit Communiqué

45 SADC 2010 www.sadc.int. 
who are represented at the highest level in the Summit, to adopt legal instruments for the implementation of the provisions of the Treaty. This mandate was clearly exercised by the August 1996 Summit through the creation and implementation of the Protocol on Trade that led to the establishment of the FTA in $2008 .{ }^{46}$

Special Summit meetings are also called to discuss issues of emergency and whenever there is a need. The Summit is a critical institution that has to approve policy before it is considered for adoption into law, for example protocol formulation. Even the judgements of the SADC Tribunal have to be referred to the Summit, since it is the only body that can sanction the findings of the Tribunal. ${ }^{47}$ Many commentators have placed the hope of SADC integration on the political willingness of regional leaders. In future, the SADC's ambitious trade timetable needs to be matched by the political will to meet the deadlines in order to restore the organisation's flagging credibility. This means that this body has to show political willingness to implement the SADC integration agenda. Unfortunately this is lacking, as regional leaders are reluctant to surrender state sovereignty for the benefit of the region.

Regional integration is a priority for the Summit. The SADC Trade Protocol itself is evidence of this need. In 2006, the Summit agreed to convene an Extraordinary Summit to discuss regional integration matters. ${ }^{48}$ The Extraordinary Summit was held in South Africa and the SADC Heads of State and Government reviewed the state of integration of the region and resolved to accord this process high priority, bearing in mind the key milestones approved by the Regional Indicative Strategic Development Plan (RISDP). The priority accorded to regional integration at the Summit suggested that political momentum seems to have developed in recent years. Subsequently, the Ordinary Summit held in Lusaka in August 2007 focused its attention on the imperatives to deepen regional economic integration and fast-track implementation of infrastructure development in the region. From there on the

46 See SADC. 2008. Summit Communiqué

47 Article 16(4) SADC Treaty (1992): "The Tribunal shall also have advisory jurisdiction at the request of the Summit or the Council of Ministers".

48 SADC 2006 www.dfa.gov.za. 
Summit has been on target in trying to implement the RISDP, as evidenced by the implementation of the FTA in August 2008. ${ }^{49}$ More functions of the Summit are enumerated under Article 10 of the SADC Treaty.

The above discussion has emphasised the importance of the Summit in SADC economic integration. As the supreme policy-making institution, it has to promote economic integration objectives if deeper integration is to be realised. The leadership of the Summit has not always been clear. As part of its structure the Summit is led by a chairman and vice-chairman elected 'for an agreed period' and 'on the basis of rotation'. ${ }^{50}$ However, the election procedures have not been specified, which has left the Heads of State and Government some latitude in the selection of the political leader of the organisation at any particular time. This leadership role is not necessarily taken on by the persons best qualified to guide the SADC agenda at any particular time; thus, regional integration efforts may be either weak or robust depending on the calibre of the current leader. This problem is not unique to the SADC, and it could be resolved by amending the SADC Treaty and giving more power to the Secretariat, which would be in charge of the daily running of the organisation. Another weakness in the role of the Summit in regional integration is that, since the Heads of State and Government cannot meet as often as there are binding decisions to be made, the efficiency of the organisation is seriously compromised.

The SADC Treaty does not state if the binding decisions of the Summit have a direct effect in the territory of Member States. The silence on the part of the SADC Treaty creates a gap in the quest for regional integration in the SADC because the manner in which decisions of the Summit are implemented is left to the discretion of Member States. To complicate matters further, it is also notable from Articles 10(8), 11(3)(6) and 13(6) that the Summit and other subsidiary organs make decisions by consensus, ${ }^{51}$ and yet there are no provisions in the Treaty for breaking an impasse where a consensus cannot be reached. In order to reach consensus, decisions are clouded in vague formulations and wide discretions that undermine legal certainty

49 SADC 2008 www.sadc.int.

50 Article 10(4) SADC Treaty (1992).

51 Articles 10(8), 11(3)(6) and 13(6) SADC Treaty (1992).

$461 / 569$ 
and are, in fact, anathema to rules-based trade.$^{52}$ This was clearly illustrated by the Summit's refusal to sanction the Tribunal judgement given against Zimbabwe in the Campbell case. ${ }^{53}$ To make matters worse, this case has led to the suspension of the Tribunal with its judges pronouncing that the actions of the July 2011 Summit clearly amounted to Tribunal dissolution, an ultra vires action on the part of the Summit. ${ }^{54}$ The Summit does not have the power to suspend the judicial arm of the SADC or any part of the Treaty. Changes can be made only by an amendment of provisions in the applicable legal instruments. Thus, the SADC Summit's decisions have given rise to serious concerns about the rule of law in the organisation. ${ }^{55}$

It is now very doubtful that the Summit will in future make decisions that are not favourable to some Member States but favourable to the region. According to Erasmus the consensus nature of decision making by the Summit gives the member in violation of its obligations veto over any sanctions. ${ }^{56}$ This point can be illustrated this way; as the Summit reaches its decisions through consensus, a Member State may decide to protect its individual interests by voting against a policy. By so doing it will prevent the achievement of the required consensus. This is a major flaw in the system. ${ }^{57}$ Given this scenario, the critical decision-making processes affecting regional integration are subjected to uncertainties to some extent. There is a need to deal with these uncertainties. One way of dealing with these uncertainties is to amend the provisions of the Treaty in order to reflect who should be in charge of making sure that Member States implement their SADC Treaty obligation. It is clear from this discussion that the Summit is playing a pivotal role in SADC regional integration at the moment and in the foreseeable future. However, as an institution of the SADC the Summit has not garnered enough political will to draw the line between the individual interest of Member States and that of the region. These challenges will have to be addressed if this organ is to remain the backbone to regional integration in the region.

\footnotetext{
52 Erasmus 2011 SADC Law Journal 130.

53 Saurombe Regionalisation 31-139.

54 Saurombe Regionalisation 279.

55 Erasmus Protection of Rights in SADC 3.

56 Erasmus Protection of Rights in SADC 3.

57 Erasmus Protection of Rights in SADC 3.
} 


\subsection{The Troika $^{58}$ and its role in SADC regional integration}

The Extraordinary Summit decided to formalise the practice of a Troika system, consisting of the Chair, the incoming Chair and the outgoing Chair of the SADC, which has been effective since it was established by the Summit in Maputo, Mozambique in $1999 .{ }^{59}$ According to Article 9(1), the Troika also applies with respect not only to the Summit but also to the Organ, the Council, the integrated Committee of Ministers and the standing Committee of Officials. ${ }^{60}$ Other members may be coopted into the Troika as and when necessary. ${ }^{61}$ This system has enabled the organisation to execute tasks and implement decisions expeditiously, as well as to provide policy direction to SADC institutions in periods between regular SADC meetings, as it is easy to convene. ${ }^{62}$ This is a key institution responsible for decision making, ${ }^{63}$ facilitating the implementation of decisions ${ }^{64}$ and providing policy direction. ${ }^{65}$ The Troika has been very functional with regard to the issues pertaining to the resolution of the Zimbabwean crisis, ${ }^{66}$ as well as the instabilities in the DRC and Madagascar.

The Troika is an important institutional organ that has to keep the integration agenda on track during its frequent meetings. Strategically, it plays a critical role in meeting more often than the Summit and its decisions and work are closely linked to the Summit. The main weakness of the Troika is its subordination to the Summit, as its resolutions can be nullified by the Summit. For example, important resolutions on Zimbabwe made at the Troika Summit of the Organ on Politics and Defence held in Livingstone, Zambia, were not endorsed by the Summit, which met the following

58 Article 9A SADC Treaty (1992).

59 SADC Date Unknown www.africa-union.org.

60 This wide scope means that the Troika is a flexible mechanism. This flexibility is evident in A 9.7, which gives each institution the power to create committees on an ad hoc basis. A 9.8 leaves the Troika of each institution to determine its own rules of procedure.

61 Erasmus Protection of Rights in SADC 3.

62 Erasmus Protection of Rights in SADC 3.

63 Article 9.6.1 SADC Treaty (1992).

64 Article 9.6.2 SADC Treaty (1992).

65 Article 9.6.3 SADC Treaty (1992).

66 SADC 2011 www.sadc.int. 
month. ${ }^{67}$ The Summit merely noted the resolution; a move that did not convey any legal significance.

It is evident in the character of the Troika that the SADC intended to foster the continuity of SADC activities. The idea of putting together an organ consisting of the current, outgoing and incoming Chairs is an ideal strategy for promoting continuity and is critical for the regional integration process, which requires an organisation that embraces change. In its practical work, the Troika will be an ideal vehicle for the full implementation of the RISDP. Another advantage for the regional integration that can be derived from the Troika is its ability to involve as many stakeholders as possible for regional integration within the SADC Treaty. Regional integration is a process that is highly likely to succeed if there is buy-in from as many stakeholders as possible.

\subsection{The Council of Ministers and its role ${ }^{68}$ in regional integration}

The function of the Council of Ministers should remain as provided for under Article 11 of the Treaty. In general, the Council serves as the engine room of the SADC in that it develops and implements the common agenda of the SADC. ${ }^{69}$ This Council consists of Ministers from each Member State, usually from the Ministries of Foreign Affairs and Economic Planning or Finance. ${ }^{70}$ The Council has an important responsibility to oversee the functioning and development of the SADC and ensure that policies are properly implemented. Under the new structure it is recommended that the Council should meet four times a year. ${ }^{71}$ Since the RISDP is still without legal basis, the Council has to facilitate its implementation and take stock of its progress in its frequent meetings. Consequently, the Council of Ministers is the direct link between the SADC and Member States, and these Ministers are mandated to express Member States' policy positions on regional matters. At the same time they play a critical role of promoting SADC initiatives in their various countries. This is

67 SADC 2011 www.sadc.int.

68 Article 11 SADC Treaty (1992).

69 Afadameh-Adeyemi and Kalula 2010 Monitoring Regional Integration in Southern Africa: Yearbook 5.

70 Saurombe Regionalisation 279.

71 Article 11(4) SADC Treaty (1992). 
critical since regional integration that lacks popular support from the ordinary citizens of Member States is bound to fail.

A very important role of this institution is its advisory role to the Summit on matters of overall policy, and the efficient and harmonious functioning and development of the SADC. ${ }^{72}$ Since the Summit normally meets once or twice a year, this advisory role is critical in keeping the most important organ of the SADC well informed of the developments around regional integration. Closely associated with this role is the Council's duty to perform such other duties as may be assigned to it by the Summit of the Treaty. ${ }^{73}$ The Council of Ministers also approves the policies, strategies and work programmes of the SADC. This role is important for regional integration; especially for programmes initiated by the RISDP. The role of convening conferences and other meetings for the purpose of promoting the objectives and programmes of the SADC is also important for regional integration. ${ }^{74} \mathrm{~A}$ number of these activities are necessary for the success of regional integration in the SADC, for example the awareness that is created through these conferences. The Council's role of considering and recommending to the Summit any application for membership ${ }^{75}$ directly influences the process of regional integration. The addition of new members to the SADC is also a mirror of the pace of regional integration in the SADC. The formation of the Tripartite FTA that includes members of the SADC, the EAC and the COMESA is testimony to the advantages associated with the increase in numbers to a regional economic community. ${ }^{76}$

The main weakness of the Council of Ministers is that it has no power to make binding decisions; it must report all of its actions to the Summit. As an institution that oversees the implementation of SADC policies, it is vital that it should have the power to make binding decisions. ${ }^{77}$

72 Article 2(3) SADC Treaty (1992).

73 Article 2(12) SADC Treaty (1992).

74 Article 2(11) SADC Treaty (1992).

75 Article 2(7) SADC Treaty (1992).

76 Saurombe Regionalisation 1.

77 Afadameh-Adeyemi and Kalula 2010 Monitoring Regional Integration in Southern Africa: Yearbook 5. 


\subsection{The Integrated Committee of Ministers and its role in regional integration}

The Integrated Committee of Ministers is made up of at least two ministers from each Member State with a mandate to meet at least once a year. This is a new institution aimed at ensuring proper policy guidance, coordination and harmonisation of cross-sectoral activities. The Integrated Committee of Ministers oversees the activities of the four core areas of integration, notably Trade, Industry, Finance and Investment; ${ }^{78}$ Infrastructure and Services; ${ }^{79}$ Food, Agriculture and Natural Resources; ${ }^{80}$ and Social and Human Development and Special Programmes, ${ }^{81}$ including the implementation of the Strategic Plan in their areas of competence. These are key area for SADC regional integration. For the purpose of emphasising the importance of this Committee, it is important to realise that the issues of trade and integration are first highlighted in the Committee. Thus, the Committee takes an initiating role in influencing policy on regional integration. The Committee comprises at least two Ministers from each Member State and should be responsible to Council. The representative nature of the Committee allows it to enjoy the support of all Member States. ${ }^{82}$ Member ownership of SADC programmes is the key to regional integration.

The Integrated Committee of Ministers also provides policy guidance to the Secretariat and makes decisions on matters pertaining to the Directorates, as well as monitoring and evaluating their work. It also has decision-making powers to ensure the rapid implementation of the programmes that would otherwise wait for a formal meeting of the Council. This is a critical characteristic, given the fact that the RISDP is faced with critical deadlines that cannot accommodate the delay attendant upon the bureaucracy of the organisation. Critically, it is tasked with monitoring and controlling the implementation of the RISDP, once approved by Council. ${ }^{83}$ 
The main challenge of this institution is that its decisions are made by consensus and are reported to the Council. ${ }^{84}$ The weakness of requiring consensus has already been emphasised during the discussion of the Summit.

\subsection{The Standing Committee of Officials ${ }^{85}$ and its role in regional integration}

The Standing Committee of Officials forms a technical advisory committee to the Council. It is made up of one permanent secretary from the ministry of the Member State which serves as the SADC national contact point. This makes this committee an important and strategic channel of information dissemination from the SADC to the Member States' national contact points; a feature that promotes awareness for economic integration among Member States. They meet at least four times a year with their decisions being made by consensus. Their frequent meetings can serve as an expediting tool for the SADC regional economic integration agenda, which has often been accused of a slow pace. Their main function is also to process documentation from the Integrated Committee of Ministers and report to the Council.

\subsection{The SADC Tribunal ${ }^{86}$ and its role in regional integration}

The SADC Tribunal is currently not operational after the decision to suspend it by the 2010 Windhoek Summit. ${ }^{87}$ The 2011 Summit put in place a further moratorium barring the Tribunal from accepting any new cases, even those not related to the Campbell case. The Summit also paralysed the Tribunal by not renewing contracts for sitting Judges or replacing them. Thus the Tribunal would be unable to accept new cases since it did not comply with the requirements for its composition as prescribed by Article 3 of the SADC Tribunal Protocol. ${ }^{88}$ Notwithstanding the current status of this judicial forum, the rationale for this discussion is to emphasise the legal mandate given to the Tribunal by the SADC Treaty and the way in which that mandate relates to regional integration. The Tribunal of the SADC is provided for

\footnotetext{
84 Article 12 SADC Treaty (1992).

85 Article 13 SADC Treaty (1992).

86 Article 16 SADC Treaty (1992).

87 SADC 2011 www.swradioafrica.com. See also Van der Bosch 2011 www.globalissues.org.

88 Scholtz 2011 SADC Law Journal 197.
} 
under Article 16 of the Declaration and Treaty Establishing the SADC of 1992. The Community's members approved the Protocol required to set up the Tribunal in the year 2000. Finally, the Protocol entered into force with the signing of the Agreement Amending the Treaty of the SADC in August 2001. This amendment signalled renewed energy in the integration of the community, making the Protocol on the Tribunal an integral part of the Treaty and thus automatically applicable to all Member States.

According to Article 16(1) of the SADC Treaty:

The Tribunal shall be constituted to ensure adherence to the proper interpretation of the provisions of the SADC Treaty and subsidiary instruments, and to adjudicate such disputes as may be referred to it.

The Tribunal is also authorised to determine, inter alia, any disputes regarding the interpretation and application of the Treaty and its Protocols that cannot be settled amicably. ${ }^{89}$ This provision is reiterated in Article 14 of the Protocol of the Tribunal. ${ }^{90}$ If the interpretation of the SADC Treaty becomes an issue, the SADC Tribunal should be an independent forum to rule on the correct interpretation or application of the legal instruments at stake. ${ }^{91}$ Persistent failure to fulfil obligations under the Treaty can result in the imposition of sanctions on the defaulting member. ${ }^{92}$ However, such sanctions can be imposed only by the Summit. ${ }^{93}$ Accordingly, sanctions can be imposed on a Member State that persistently, without good reason, fails to fulfil its obligations assumed under the SADC Treaty. ${ }^{94}$ However, in view of the Summit's consensus-based character, resorting to such drastic measures is not contemplated, since the defaulting member would have to support the sanction resolutions. ${ }^{95}$

89 Article 3 SADC Treaty (1992).

90 According to A 16.2 SADC Treaty (1992), the composition, powers, functions, procedures and other related matters governing the Tribunal shall be prescribed in a Protocol, which shall, notwithstanding the provisions of A 22 of the Treaty, form an integral part of the Treaty, adopted by the Summit.

91 Erasmus 2011 SADC Law Journal 130.

92 Article 33 SADC Treaty (1992).

93 Article 33.2 SADC Treaty (1992).

94 Article 33.1 SADC Treaty (1992).

95 Article 10(8) SADC Tribunal Protocol (2008). 
The Tribunal is critical for the integration process for the SADC, as it provides a legal guidance to all SADC institutions and, most importantly, can play an oversight role during the implementation stages of the integration agenda. Its decisions are final and binding. ${ }^{96}$ If the SADC is truly rules based, the rulings by the Tribunal will normally be binding on the parties involved. ${ }^{97}$

However, the discussion of the SADC Tribunal points to its apparent weaknesses and, most importantly, the Summit's failure to sanction its judgment on the Campbell case. $^{98}$ On 28 November 2008, the SADC Tribunal ruled that 78 white Zimbabwean farmers could keep their farms because the Zimbabwean land reform programme had discriminated against them. ${ }^{99}$ The Zimbabwean Government rejected this ruling, challenging its legality and lobbied the Summit to suspend the Tribunal. The Tribunal was dully suspended in August 2010, pending an independent six-month review of its "role, functions and terms of reference". ${ }^{100}$

The review process was required to address inter alia the jurisdiction of the Tribunal; the interface between Community law and national laws in the SADC; the mandate of the existing appeals chamber of the Tribunal; the recognition, enforcement and execution of the Tribunal's decisions; the lack of clarity in some provisions of the SADC Treaty and the Tribunal Protocol; the tendency by Member States to give primacy to domestic laws or jurisdiction over SADC law; and the reluctance of Member States to relinquish some aspects of their sovereignty to the SADC. ${ }^{101}$ However, after the review was completed, the SADC justice ministers and attorney generals questioned anew its fundamental elements and then initiated a new, partisan review. This led the June 2011 Summit to suspend all work for the Tribunal, going so far as to stop it from hearing new cases unrelated to the Campbell case. The decision not to reappoint or replace the Tribunal's 10 judges rendered the

96 Article 16.5 SADC Treaty (1992).

97 Erasmus 2011 SADC Law Journal 130.

98 Mike Campbell $v$ Republic of Zimbabwe SADC (T) 2/2007 (28 November 2008).

99 Ebobrah 2009 Afr Hum Rts L J 329.

100 Scholtz 2011 SADC Law Journal 197.

101 Scholtz 2011 SADC Law Journal 197. 
Tribunal inoperative until at least August 2012. The remaining four judges ${ }^{102}$ of the SADC Tribunal described this move as amounting to the dissolution of the Tribunal altogether. This is contrary to the findings of the review process, which had even found that the Tribunal's ruling was legitimate and suggested a need for the further strengthening of the Tribunal.

The Tribunal had acted within its mandate when it took the decision in accordance with Article 32(5) of the Protocol on the Tribunal to make a report of non-compliance to the Summit of the SADC. However, this procedure shows the handicap of international judicial institutions in terms of their inability to enforce their own decisions. The SADC Tribunal does not have its own judgement enforcement mechanism; it relies on Member States to enforce its decisions. ${ }^{103}$ Article 32(1) of the Protocol on the Tribunal requires the decisions of the Tribunal to be registered and enforced by Member States as foreign judgements. ${ }^{104}$ This creates a gap in the enforcement of the Tribunal's decisions because it subjects the enforcement of the Tribunal decisions to domestic laws that govern the enforcement of foreign judgements in Member States. ${ }^{105}$ This provision is an example of a matter on which the SADC instruments are unclear and deserve urgent attention and clarification. ${ }^{106}$

The weakness of the above mechanism played itself out when in the case of Gramara (Pty) Ltd and one other $v$ The Government of the Republic of Zimbabwe and two others (HC 33/09) [2010] ZWHHC1 the Zimbabwe High Court refused to register and enforce a judgement of the Tribunal on the grounds that the decision of the Tribunal was contrary to public policy in the Republic of Zimbabwe. Zimbabwe's action is contrary to the spirit of regional integration and sends out a wrong message that Member States can undermine regional jurisprudence or fail to honour their

102 These judges include the Tribunal President, Mauritius Chief Justice Ariranga Pillay and Justices Rigoberto Kambovo, Onkemetse Tshosa and Frederick Chomba.

103 Scholtz 2011 SADC Law Journal 197.

104 Afadameh-Adeyemi and Kalula 2010 Monitoring Regional Integration in Southern Africa: Yearbook 5.

105 Afadameh-Adeyemi and Kalula 2010 Monitoring Regional Integration in Southern Africa: Yearbook 5.

106 Scholtz 2011 SADC Law Journal 197. 
obligations under the relevant regional instruments. ${ }^{107}$ Accordingly, if regional integration is to be firmly rooted within the SADC, the SADC Tribunal must be allowed to develop the jurisprudence of SADC law, as was the case with the European Court of Justice in the formative years of the European Union. ${ }^{108}$

This discussion demonstrates that political organs of international institutions are vital for the creation of a culture of compliance. ${ }^{109}$ The actions of the Summit are actually illegal since, without amending the SADC Treaty and Protocol on the Tribunal, the Summit has no power to restrict the Tribunal's jurisdiction or to overrule the protocol. The suspension of the Tribunal as a result of a Member State's dissatisfaction with the decisions of the Tribunal casts doubt on the acceptability of decisions of supranational institutions by SADC Member States.

On the assumption that the Tribunal will be reinstated, its influence and credibility have already been eroded. If it is envisaged that the Tribunal will then be called upon in the near future to decide on issues relating to regional integration, and if the Zimbabwean experience is used as a precedent, Member States may get away without being sanctioned after a breach of their obligations under the SADC Treaty. This is a dangerous precedent for an institution that is entrusted with developing the jurisprudence of the region. ${ }^{110}$ The Summit can, at will, decide to make decisions that directly impact on the path of regional integration in SADC. There are already several integration breaches that are happening in the region, especially to the citizens of the region. An example is the charging of high tariffs on imports. This state of affairs was supposed to end by the time of the establishment of the FTA in 2008. The FTA covers 85 per cent of all goods except motor vehicles and parts, as well as clothing material. However, high tariffs on substantially all trade in goods are still being reported in the region. The Tribunal is the most relevant forum to address

107 Afadameh-Adeyemi and Kalula 2010 Monitoring Regional Integration in Southern Africa: Yearbook 5.

108 Arnull European Union 76

109 In terms of the organisational structure of SADC, the Summit is made up of Heads of State and Government and is the highest authority of the SADC.

110 Afadameh-Adeyemi and Kalula 2010 Monitoring Regional Integration in Southern Africa: Yearbook 5. 
these issues because the court has jurisdiction to hear matters affecting private citizens. ${ }^{111}$

The Tribunal is empowered by the Treaty to apply SADC law without fear or favour and to pave the way for the harmonisation of business law to the extent that these laws can also be applied by the Tribunal. ${ }^{112}$ The harmonisation of policies or the adoption of similar policies is a signal that a regional arrangement is seeking to achieve a high degree of economic integration. ${ }^{113}$ The drastic action taken to dissolve the Tribunal has sent the worst possible signal to the SADC region and to potential investors and the whole international community, reflecting the SADC's poor record on human rights, democracy and the rule of law. ${ }^{114}$

\subsection{The Secretariat ${ }^{15}$ and Executive Secretary's role in regional integration}

The SADC Secretariat is the principal executive institution of the SADC responsible for the strategic planning, coordination and management of SADC programmes. ${ }^{116} \mathrm{It}$ is headed by an Executive Secretary and has its headquarters in Gaborone, Botswana. ${ }^{117}$ The Extraordinary Summit agreed that the Secretariat should be strengthened in terms both of its mandate and of the provision of adequate resources for it to be able to perform its functions effectively as provided for under Article 14 of the SADC Treaty and in accord with the Abuja Treaty. Currently the Secretariat is involved in a robust exercise of recruiting additional staff that will help speed up the process of integration. The SADC Secretariat's main functions are to spearhead the strategic planning and management of the SADC programme. ${ }^{118} \mathrm{It}$ is also tasked with implementing the decisions of the Summit and Council. This is a key responsibility with specific reference to the SADC's regional integration agenda, and the implementation of the FTA, customs union and common market falls within the

111 See Mondlane v SADC Secretariat SADC (T) 7/2009 (5 February 2010); Kanyama v SADC Secretariat SADC (T) 5/2009 (29 January 2010).

112 Saurombe Saurombe 2011 "The Southern African Development Community" 1-33.

113 Goode Dictionary of Trade Policy Terms 359.

114 Erasmus 2011 SADC Law Journal 17-34.

115 Article 14 SADC Treaty (1992).

116 Article 14.1.1 SADC Treaty (1992).

117 Article 2.2 SADC Treaty (1992).

118 Article 14.1.2 SADC Treaty (1992). 
mandate of the Secretariat. The SADC Secretariat will be called upon to vigorously pursue SADC-related objectives in the negotiations and implementation of the SADC, EAC and COMESA Tripartite FTA.

The task of organising and managing the SADC meetings also rests on the shoulders of the Secretariat: ${ }^{119}$ hence the timeframe of the full implementation of the RISDP has to be done properly. The responsibility for financial and general administration ${ }^{120}$ is critical for the SADC integration agenda and funding for the implementation of the RISDP has to be properly managed. Since SADC depends mostly on donor funding, proper management and administration of such is critical if the SADC wishes to secure future funding. The SADC Secretariat is called upon to mobilise financial support from both the private and public sector stakeholders for the purpose of funding regional integration programmes like transport corridors. ${ }^{121}$

The representation and promotion of the SADC is also a key responsibility of the Secretariat, ${ }^{122}$ as the SADC requires key representation at regional and multilateral levels. The SADC is highly regarded in Africa as one of the most promising RECs. This reputation is based on to SADC's image and vision when compared with those of the other RECs operating in Africa. In addition, the SADC has already been identified by the African Union as one of the key pillars for the Africa Economic Community (AEC). The Secretariat also represents the SADC outside the African continent. On 29 March 2010 the SADC Executive Secretary, Dr Tomaz Augusto Salomão, signed a cooperation framework agreement with the Government of the Federative Republic of Brazil on behalf of the SADC in Brasilia, Brazil. The objective of the Agreement between the Government of the Federative Republic of Brazil and the SADC is to promote the economic, industrial, scientific and technological development of the people of Brazil and the SADC region. The priority areas for cooperation include, inter alia, infrastructure development with a special emphasis on energy, food security, information and communication technology, and science 
and technology. These are critical areas for the full implementation of the RISDP, in line with the drive for the development of capacity. ${ }^{123}$

The infrastructure problem has been identified as one of the challenges for regional integration in the SADC. The cooperation and partnership between the Government of the Federative Republic of Brazil and the SADC is intended to take the following forms: the formulation and implementation of programmes and projects in areas of common interest, the exchange of information, the undertaking of internships and technical missions, the organisation of seminars, meetings and trainee programmes, as well as the development of research studies on areas of common interest. All of these aspects touch on technology transfer, a critical area for development in Southern Africa. On the same day the SADC also signed an Agreement with the Community of Portuguese Speaking Countries (the CPLP) on the Provision of Financial Support for the Translation of the Content of the SADC Website into Portuguese. In terms of the Agreement, the CPLP will provide the financial support for the translation of the content of the SADC website into Portuguese. ${ }^{124}$ Such a translation will be useful for the SADC since Mozambique and Angola are Portuguese-speaking countries, whose optimal participation in SADC programmes has always been hampered by the language barrier. Deeper integration will be enhanced through this effort.

The Secretariat plays a critical role in the promotion and harmonisation of the policies and strategies of Member States. ${ }^{125}$ The task of exercising this mandate is important at this critical phase of the FTA and customs union, as these stages require that Member States find a common ground on the elimination of all trade barriers for the FTA, as well as a compromise on a common external tariff (CET) acceptable to all Member States. The common external tariff will be a challenge, since the lowest level in existence in the proposed CU has to be adopted. Mauritius tariffs have already reached zero, hence the CET cannot go beyond that. With most SADC members still relying on tariffs as sources of revenue, a common ground will be difficult to find and an agreement can be achieved only once individual states' 
policies are harmonised. Common strategies to achieve common objectives are the starting point that the Secretariat is tasked to promote. The Secretariat has also been given a mandate to drive appropriate strategies for self-financing and incomegenerating activities and investments, as well as undertaking research on community building and the integration process.

The biggest challenge for the Secretariat is still the apparent reluctance on the part of Member States to surrender national initiative and active representativeness to the principle of supra-nationalism. ${ }^{126}$ The Secretariat is also poorly funded and relies mostly on donor funds. Comparisons can be drawn with like bodies in other regions, like Association of South-Eastern Asian Nations (ASEAN). ${ }^{127}$ Hafeez $^{128}$ observes that:

[t]he ASEAN Secretariat is understaffed and underfunded, has no open recruitment, staff seconded by member states.

The governments of SADC Member States still fill most positions within the Secretariat by way of secondment. When jobs are advertised, interested candidates have to apply through each Member State's national contact point ${ }^{129}$ and applications made directly to the Secretariat are not considered.

\section{An analysis of the role of SADC institutions in regional integration}

It is apparent therefore that the transformation from the SADCC to the SADC has not completely brought about the creation of supranational institutions. The current SADC institutional structure is not supranational because it is not independent of individual Member States. According to Tallberg: ${ }^{130}$

Supranational institutions are largely independent of individual Member States and they are vested with decision-making powers which bind Member States.

126 Evans, Holmes and Mandaza SADC.

127 ASEAN Date Unknown www.asean.org.

128 Hafez Dimensions of Regional Trade Integration.61.

129 Article 16A SADC Treaty (1992).

130 Tallberg 2002 West European Politics 23-46. 
This is not the case with the SADC. Evidence from the dissolution of the SADC Tribunal clearly shows that SADC institutions are not independent of the influence of Member States. Furthermore, key institutions within the organisation should work in harmony and exercise their powers in a manner that reflects the common agenda of the regional body. The SADC Summit is clearly playing a bullying role on the institutions which report to it. The current SADC setup creates institutions which only resemble supranational institutions. The pertinent outcome of this analysis is that the SADC institutional framework is not independent of the influence of Member States. The requirement of consensus in decision making for all institutions also weakens the organisation. These institutions therefore cannot be fully relied upon to propel the SADC towards deeper regional integration.

\section{Recommendations on how the law can address the problems of poor treaty implementation}

Firstly, the discussion of the different treaty provisions giving the SADC's institutions a mandate to pursue regional integration indicates that the organisation is rules based, and a deliberate effort should therefore be made to ensure respect of its rules. ${ }^{131}$ The Tribunal has confirmed certain aspects of this rules-based system. ${ }^{132}$ The shortcomings of the SADC Treaty are mostly evident from the excessive powers given to and employed by the Summit. It is recommended that the Summit's powers be limited. It must not be possible for the Summit to undermine the efforts of the other institutions. This paper has identified the Tribunal as the most appropriate institution to be mandated to keep the Summit in check, instead of which the Summit has actually rendered the Tribunal inoperative. It is recommended that the Tribunal be reinstated in order to resume its role as the custodian of the rule of law in the SADC.

The issue pertaining to the monitoring of the implementation of SADC Treaty provisions would also be enhanced by the reinstatement of the Tribunal, since the Tribunal was "constituted to ensure adherence to and the proper interpretation of the

131 Erasmus 2011 SADC Law Journal 130.

132 Erasmus 2011 SADC Law Journal 130; see also Mike Campbell v Republic of Zimbabwe SADC (T) 2/2007 (28 November 2008). 
provisions of the SADC Treaty and subsidiary instruments and to adjudicate upon such disputes as may be referred to it". Its decisions are final and binding. ${ }^{133}$ Thus the SADC Tribunal is ideally placed to monitor the powers of other institutions such as the Summit. The Tribunal should play the equally important role of making sure that SADC institutions implement the SADC Treaty provisions that they are charged with.

SADC law can address the problems of poor implementation and the insufficient monitoring of compliance by imposing sanctions on members who "persistently fail, without good reason, to fulfil obligations assumed under this Treaty" or when they "implement policies which undermine the principles and objectives of SADC". ${ }^{134}$ Applying these legal provisions could have easily resulted in the imposition of sanctions on Zimbabwe for having failed to comply with the SADC Tribunal's rulings on its human rights violations. It is part of the operational challenge in the SADC that compliance with international obligations is not being properly monitored, and there are no effective ways of enforcing sanctions for non-compliance.

It is also recommended that the registration of Tribunal judgements in Member States be performed in order to be able to give domestic effect to the rulings of the Tribunal. There is a need to create more awareness in SADC Member States parliaments of the need to adopt international agreements. For example, the South African Constitution makes specific provision for the responsibility of the national executive in signing international agreement. ${ }^{135}$ This is in line with the 'general undertakings' listed in Article 6 of the SADC Treaty, that provides that Member States "shall take all steps necessary to ensure the uniform application of this Treaty" as well as "all necessary steps to accord this Treaty the force of international law". This means that Article 6(5) prescribes that the Treaty needs to be given effect within the Member States. It is recommended that Member States comply with this requirement, and in cases where the relevant national legislation is not available, new legislation may be required. Member States need to respect these provisions. 


\section{Conclusion}

The SADC Treaty and Protocol on Trade provides a solid legal and institutional platform for its Member States to integrate their economies. Each and every SADC institution discussed in this paper has a unique role to play in this regional integration process. The debate on the success of the SADC regional economic integration agenda has not been the focus of this study; hence, it will not be concluded here. However, it is very important to realise that, in the current SADC legal and institutional framework, though it is not adequate, the effort of putting the SADC on the road to regional integration has not gone unrewarded. With the kind of legal mandate given by the SADC Treaty to the various institutions discussed in this paper, it can be concluded that the SADC Treaty is very ambitious on paper, but the institutions have a poor record with regard to implementation. Erasmus also concludes that "the question marks are not about the formal legal dimension: it is mostly about poor implementation and insufficient monitoring of compliance". ${ }^{136}$

This paper has demonstrated that SADC institutions are not capable of completely fulfilling their legal obligations, although in some instances the lack of fulfilment was clearly a result of the legal instruments themselves being incomplete and needing further reform. The Summit's failure to respect the judgments of the Tribunal is a clear example. The de facto suspension of the Tribunal subsequent to Zimbabwe's non-compliance with its orders creates the impression that SADC members are not committed to regional integration under the auspices of the SADC. ${ }^{137}$ It can also be concluded that SADC Member States neglect their legal obligations to fulfil the obligations of the Treaty. The full implementation of the 2008 FTA and the enforcement of the judgments of the Tribunal would contradict this statement, if they were to take place. Thus, under the current legal and institutional framework, the $S A D C$ 's regional integration agenda faces major challenges of implementation. The SADC's legal arrangements should be seen as constituting binding and enforceable law which must be implemented before national and regional courts. 


\section{Bibliography}

Abegunrin "Southern African Development Coordination Conference"

Abegunrin L "The Southern African Development Coordination Conference: Politics of Dependence" in Onwuka RI and Sesay A (eds) The Future of Regionalism in Africa (Macmillan London 1985)

Abegunrin 1981-2 Current Bibliography on African Affairs

Abegunrin L "The Southern Nine" 1981-2 Current Bibliography on African Affairs 14(4) 1-5

Afadameh-Adeyemi and Kalula 2010 Monitoring Regional Integration in Southern Africa: Yearbook

Afadameh-Adeyemi A and Kalula E "SADC at 30: Re-examining the Legal and Institutional Anatomy of the Southern African Development Community" 2010 Monitoring Regional Integration in Southern Africa: Yearbook 5-22

Arnull European Union

Arnull A The European Union and its Court of Justice (Oxford University Press New York 1999)

Clough and Ravenhill "Regionalism in Southern Africa"

Clough $M$ and Ravenhill $J$ "Regionalism in Southern Africa: the SADCC" in Clough M (ed) Political Change in Southern Africa (University of California Berkeley 1982)

Ebobrah 2009 Afr Hum Rts L J

Ebobrah $S$ "Human Rights Developments in Sub-regional Courts in Africa During 2008" 2009 Afr Hum Rts L J 312-335

Erasmus Protection of Rights in SADC

Erasmus G What has Happened to the Protection of Rights in SADC?

(Tralac Stellenbosch 2012) 


\section{Erasmus 2011 SADC Law Journal}

Erasmus G "Is the SADC Trade Regime a Rules-based System?" 2011 SADC Law Journal 17-34

Evans, Holmes and Mandaza SADC

Evans D, Holmes P and Mandaza I SADC: The Cost of Non-integration (SAPES Books Harare 1999)

Ferrari and Pollicino 2011 Comparative Law Review

Ferrari GF and Pollicino O "The Impact of supranational law on the national sovereignty of member states, with particular regard to the judicial reaction of UK and Italy to the new aggressive approach of the European Court of Human Rights" 2011 Comparative Law Review 1-63

Gibb 1998 JMAS

Gibb R "Southern Africa in transition: prospects and problems facing regional integration" 1998 JMAS 287-306

Goode Dictionary of Trade Policy Terms

Goode W Dictionary of Trade Policy Terms (Cambridge University Press Cambridge 2003)

Hafez Dimensions of Regional Trade Integration

Hafez Z The Dimensions of Regional Trade Integration in Southeast Asia (Transnational Ardsley 2004)

Kaunda "Address"

Kaunda K "Address" (Unpublished speech delivered at the Lusaka Economic Summit of the Southern African Development Coordination Conference in Lusaka 1 April 1980)

Khama 1979 Africa Research Bulletin

Khama S 1979 (June 15-July 14) Africa Research Bulletin 51-55 
Kiljunen European Constitution in the Making.

Kiljunen $\mathrm{K}$ The European Constitution in the Making (Centre for European Policy Studies Brussels 2004)

Maruping "Challenges for Integration"

Maruping $M$ "Challenges for Integration in Sub Saharan Africa: Macroeconomic Convergence and Monetary Coordination" in Teunissen JJ and Akkerman A Africa in the World Economy: The National, Regional and International Challenges (FONDAD The Hague 2005)

Mattli The Logic of Regional Integration Mattli W The Logic of Regional Integration: Europe and Beyond. Cambridge: (Cambridge University Press 1999).

Mutharika Towards Multinational Economic Cooperation

Mutharika B Towards Multinational Economic Cooperation in Africa (Praeger New York 1972)

Ng'ong'ola 1999 Journal of World Trade

Ng'ong'ola C "Regional Integration and Trade Liberalisation in Africa: The Treaty for the Establishment of an African Economic Community Revisited in the Context of the WTO System" 1999 Journal of World Trade 145-171

Nsekela Southern Africa

Nsekela AJ Southern Africa: Toward Economic Liberation (Collings London 1981)

Olivier "Southern African Development Community"

Olivier NJJ "Southern African Development Community" in EU Commission for Democracy Through Law Federal and Regional States in the Perspective of EU Integration (Council of Europe Strasbourg 1999) 
Oosthuizen Southern African Development Community

Oosthuizen GH The Southern African Development Community: The Organisation, Its Policies and Prospects (Institute for Global Dialogue Midrand 2006)

Saurombe Regionalisation

Saurombe A Regionalisation through economic integration in SADC (LLDthesis North West University 2011).

Saurombe 2011 "The Southern African Development Community"

Saurombe A "The Southern African Development Community (SADC) Trade Legal Instruments Compliance with Certain Criteria of GATT Article XXIV" 2011 14(4) PER 1-33

Scholtz 2011 SADC Law Journal

Scholtz W "Review of the role, functions and terms of reference of the SADC Tribunal" 2011 SADC Law Journal 197-201

Tallberg 2002 West European Politics

Tallberg J "Delegation to Supranational Institutions: Why, How, and With What Consequences?" 2002 West European Politics 23-46

Thompson Challenge to Imperialism

Thompson CB Challenge to Imperialism: The Frontline States in the Liberation of Zimbabwe (Westview Boulder 1985)

Tsikata "Southern Africa: Trade, Liberalisation and Implications"

Tsikata $Y$ "Southern Africa: trade, liberalisation and implications for a free trade area" (Unpublished paper presented at the Annual Trade and Industrial Policy Secretarial Forum in Muldersdrift 1999) 


\section{Register of case law}

Kanyama v SADC Secretariat SADC (T) 5/2009 (29 January 2010)

Mike Campbell v Republic of Zimbabwe SADC (T) 2/2007 (28 November 2008)

Mondlane $v$ SADC Secretariat SADC (T) 7/2009 (5 February 2010)

Gramara (Pty) Ltd and one other $v$ The Government of the Republic of Zimbabwe and two others (HC 33/09) [2010] ZWHHC1

\section{Register of treaties, instruments and legislation}

Constitution of the Republic of South Africa, 1996

Harare Memorandum of Understanding (1981)

Lusaka Declaration (1980)

SADC Tribunal Protocol (2008)

SADC Protocol on Trade (1996)

SADC Treaty (1992)

\section{Register of Internet sources}

ASEAN Date Unknown www.asean.org

ASEAN Date Unknown Home page www.asean.org [date of use 5 Jun 2012]

Jakobeit, Hartzenberg and Charalambides 2005 www.acp-eu-trade.org

Jakobeit C, Hartzenberg T and Charalambides N 2005 Overlapping Membership in COMESA, EAC, SACU and SADC: Trade Policy Options for the Region and for EPA Negotiations - Summary of Findings www.acp-eutrade.org/library/files/Jakobeit-Hartzenberg-Charalambides_05_Overlappingmembership.pdf [date of use 30 May 2012]

Mutua 2007 allafrica.com

Mutua M 2007 'East Africa: We celebrated at EAC collapse, says Njonjo' The Standard 17 of May 2007 allafrica.com/stories/200705170023.html [date of use 30 May 2012] 
SADC. 2008. Summit Communiqué:

SADC. 2008. Summit Communiqué: Final Communiqué of the 28th Summit of SADC Heads of State and Government. Held in Sandton, Republic of South Africa from August 16 to 17, 2008. [Online]. Available:

http://www.sadc.int/index/browse/page/203 [ date of use 17 July 2012]

SADC Date Unknown www.africa-union.org

SADC Date Unknown Official Publication of Establishment of the SADC Troika www.africa-union.org/root/au/recs/sadc.htm\#institutions [date of use 1 Jun 2012]

SADC Date Unknown www.sadc.int

SADC Date Unknown Home page www.sadc.int [date of use 10 Jun 2011]

SADC 2006 www.dfa.gov.za

SADC 2006 Final Communique of the SADC Extraordinary Summit of the Heads of State and Government to consider the Regional, Economic and Political Integration www.dfa.gov.za/docs/2006/sadc1026.htm [date of use 1 Jun 2012]

SADC 2008 www.sadc.int

SADC 2008 Official Communiqué of the SADC Summit www.sadc.int/english/regional-integration/tifi/sadc-free-trade-area/ [date of use 1 Jun 2012]

SADC 2010 www.sadc.int

SADC 2010 Communiqué of the 30th Jubilee Summit of SADC Heads of State and Government, 16-17 August 2010 www.sadc.int/index/browse/ page/782 [date of use 1 Jun 2012] 
SADC 2011 www.sadc.int

SADC 2011 Communique from the Organ Troika on Politics, Defence and Security Cooperation, 31 March 2011, Livingstone, Zambia www.sadc.int/index/browse/page/858 [date of use 4 Jun 2012]

SADC 2011 www.swradioafrica.com

SADC 2011 Communiqué of 20 May 2011 (Section 7 and 8) www.swradioafrica.com/Documents/SADCSummit240511.pdf [date of use 5 Jun 2012]

Van der Bosch 2011 www.globalissues.org

Van der Bosch S 2011 Southern Africa: Very little 'extraordinary' about latest SADC Summit www.globalissues.org/news/2011/05/22/9750 [date of use 5 Jun 2012]

\section{List of abbreviations}

AEC

Afr Hum Rts L J

ASEAN

CET

COMESA

CPLP

EAC

FTA

J Int'I Econ L

JMAS

RECS

RISDP

RTAs

SADC

SADCC
Africa Economic Community

African Human Rights Law Journal

Association of South-Eastern Asian Nations

Common external tariff

Common Market for Eastern and Southern Africa

Community of Portuguese Speaking Countries

East African Community

Free Trade Area

Journal of International Economic Law

Journal of Modern African Studies

Regional Economic Communities

Regional Indicative Strategic Development Plan

Regional trade agreements

Southern African Development Community

Southern African Development Coordination Conference 